\title{
Magnesium Ion-Selective Optodes Based on a Neutral Ionophore and a Lipophilic Cationic Dye
}

\author{
Dwi Siswanta*, Hideaki Hisamoto*, Sayaka Sato*, Yukihiro Matsumoto*, \\ Yasuhiro KolkE*, Shinji YAMAMORI** and Koji SuzUkI*† \\ * Department of Applied Chemistry, Keio University, Hiyoshi, Kohoku-ku, Yokohama 223, Japan \\ ${ }^{* *} R \& D$ Center, Biomedical Engineering Section, Nihon Kohden Corporation, \\ 1-31-4, Nishiochiai, Shinjuku-ku, Tokyo 161, Japan
}

\begin{abstract}
Flow-through type magnesium ion-selective optodes based on a neutral ionophore and a lipophilic cationic dye have been developed. The optodes were prepared by coating pellicular octadecylsilica beads with a lipophilic organic liquid containing magnesium ionophores, a lipophilic cationic dye and a lipophilic anionic additive, and packing the beads into a flow-through optical cell. Two neutral magnesium ionophores (K22B5 and K22B1B5) and two novel lipophilic cationic dyes (KDC-1 and KDC-2) were synthesized and tested for preparing the optodes. Among the developed optodes, an optode based on the ionophore K22B1B5 and a cationic dye (KDC-2) produced the best magnesium ion optode with a relatively high $\mathrm{Mg}^{2+}$ sensitivity and selectivity. This optode showed a fast and reproducible response to magnesium ion, even in a high concentration of background ions.
\end{abstract}

Keywords Optode, neutral ionophore, magnesium ion, cationic dye

Following the successful achievement of applying neutral ionophores as a membrane component of an ISE, many novel optodes for cations and anions based on neutral ionophores have been developed in recent years by us ${ }^{1-4}$ and others. ${ }^{5-11}$ Unfortunately, there has been no report concerning the development of magnesium ionselective optodes, which is mainly caused by the lack of a highly selective magnesium ionophore. In practical use, such as in the assay of $\mathrm{Mg}^{2+}$ in blood serum ${ }^{12,13}$, and intracellular liquids ${ }^{14-16}, \mathrm{Ca}^{2+}, \mathrm{K}^{+}, \mathrm{Na}^{+}$and $\mathrm{Li}^{+}$cause the most serious interference in the sensing of magnesium ion; therefore, a highly selective magnesium ionophore is crucially needed in order to obtain an excellent magnesium ion-selective optode.

Recently, we have reported on the development of novel magnesium ionophores based on a malonamide subunit attached to an azacrown compound. ${ }^{17}$ Among them, a magnesium ionophore (K22B5), which has two bulky adamantyl units in the side chain of the azacrown compound, was found to exhibit the highest magnesium selectivity in potentiometric studies; ${ }^{17}$ however the lipophilicity is not sufficient for use in a flow-analysis system. We thus synthesized a new magnesium ionophore (K22B1B5 (one octadecyl chain and one adamantyl unit in the side chain)) as a compromise of high selectivity and high lipophilicity.

\footnotetext{
$\dagger$ To whom correspondence should be addressed.

D.S. On leave from Department of Chemistry, Gadjah Mada University, Sekip Utara, Jogjakarta, Indonesia.
}

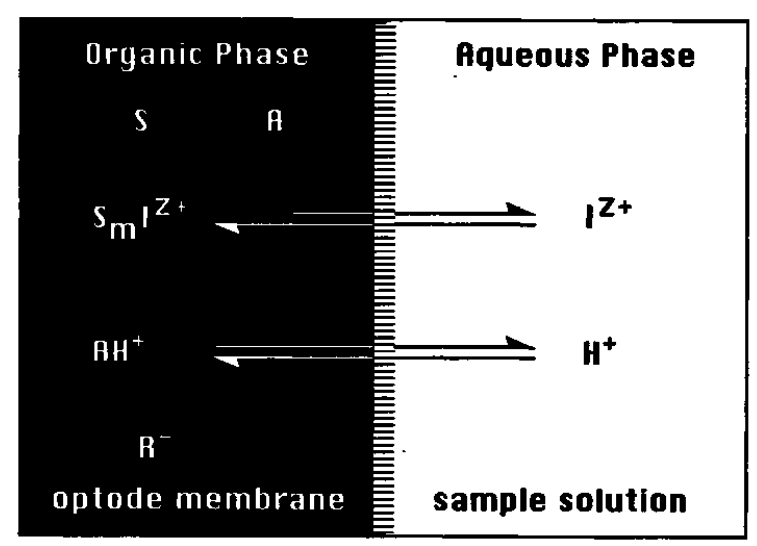

Fig. 1 Ion-extraction model for the ion optode response: S, neutral ionophore; A, lipophilic dye; $\mathrm{I}^{z^{+}}$, ion to be sensed.

The optical response principle of the developed $\mathrm{Mg}^{2+}$ optode is based on an ion-pair formation reaction, as illustrated in Fig. 1, and expressed as follows: ${ }^{18,19}$

$$
\begin{aligned}
& \mathrm{Iaq}_{\mathrm{aq}}^{\mathrm{z}+}+m \mathrm{~S}_{\mathrm{o}}+z \mathrm{AH}_{\mathrm{o}}^{+}=\left(\mathrm{S}_{m} \mathrm{I}^{{ }^{+}+}\right)_{\mathrm{o}}+z \mathrm{~A}_{\mathrm{o}}+z \mathrm{H}_{\mathrm{aq}}^{+}, \\
& {\left[\mathrm{R}^{-}\right]_{\mathrm{o}}=\left[\mathrm{AH}^{+}\right]_{\mathrm{o}}+z\left[\mathrm{~S}_{m} \mathrm{I}^{++}\right]_{\mathrm{o}},}
\end{aligned}
$$

where I, S and A denote cation, neutral ionophore, and cationic dye, respectively. $\mathrm{S}_{m} \mathrm{I}^{2^{+}}$is the complex species formed by the neutral ionophore and the cation. 
Subscripts $o$ and aq denote the organic and aqueous phases, respectively. A lipophilic anionic additive ( $\mathrm{R}^{-}$(in this investigation, sodium tetrakis[3,5-bis(trifluoromethyl)phenyl]borate, TFPB was used)) was added to the organic phase in order to maintain the electroneutrality (see Eq. (2)). Based on this reaction, the cation extraction from the aqueous phase and complex formation with the neutral ionophore organic phase were followed by the release of a proton from the protonated lipophilic cationic dye into the aqueous phase. As a result, a color intensity change in the dye was observed, which could be measured spectrophotometrically in the absorbance mode, which corresponded to the concentration of the $\mathrm{AH}^{+}$in the organic phase. In this report we examine the performance of the magnesium optodes based mainly on a newly synthesized ionophore (K22B1B5) and lipophilic cationic dye (KDC-1 or KDC-2).

\section{Experimental}

\section{Reagents}

Reagents of the highest grade commercially available were used for the synthesis of novel magnesium ionophores, lipophilic cationic dyes and the preparation of aqueous test electrolytes. The distilled and deionized water used had resistivity values of more than $1.5 \times 10^{7} \Omega$ $\mathrm{cm}$ at $25^{\circ} \mathrm{C}$. Pellicular ODS beads were purchased from Merck AG (Darmstadt, Germany; Perisorb RP-18, $30-40 \mu \mathrm{m}$ particle size, $c a .2 \mu \mathrm{m}$ modified layer thickness). The lipophilic organic liquid NPOE (o-nitrophenyl octyl ether) was purchased from Dojindo Laboratories, Kumamoto, Japan, and was used as received.

\section{Synthesis of ionophores and lipophilic cationic dyes}

The preparation of K22B5 (4,13-[bis $(N$-adamantylcarbamoyl)acetyl]-1,7,10,16-tetraoxa-4,13-diazacyclooctadecane) was described in a previous report. ${ }^{17}$ K22B1B5, KDC- 1 and KDC-2 were synthesized as follows:

K22B1B5 (4-( $N$-octadecylcarbamoyl)acetyl-13- $(N$ adamantylcarbamoyl)acetyl-1,7,10,16-tetraoxa-4,13diazacyclooctadecane). Monomethyl malonate potassium salt $(4.0 \mathrm{~g}, 25.6 \mathrm{mmol})$ was suspended in $\mathrm{CH}_{2} \mathrm{Cl}_{2}$ $(20 \mathrm{ml})$. $\mathrm{SOCl}_{2}$ was then added to the suspension at $0^{\circ} \mathrm{C}$, and the reaction mixture was stirred at room temperature for $2 \mathrm{~h}$. A precipitated white crystal was filtered off, and the filtrate was concentrated to yield monomethylmalonylchloride as a yellowish liquid. Octadecylamine $(6.89 \mathrm{~g}, 25.6 \mathrm{mmol})$ was dissolved in $\mathrm{CH}_{2} \mathrm{Cl}_{2}(20 \mathrm{ml})$ and stirred. Monomethylmalonylchloride was slowly added to the mixture at $0^{\circ} \mathrm{C}$. The reaction mixture was stirred at room temperature for $1 \mathrm{~d}$ and dissolved in chloroform. The mixture was extracted twice by an $\mathrm{HCl}$ solution (pH 2) and water. The organic phase was evaporated, and the residue was purified by column chromatography (silica gel, hexane/ ethylacetate $1: 1)$ to yield $600 \mathrm{mg}(5.3 \%)$ of ( $N$-Octadecylcarbamoyl)methylacetate as a white powder. ( $N$-Octa- decylcarbamoyl)methylacetate $(540 \mathrm{mg}, 1.92 \mathrm{mmol})$ was added to a mixture of methanol/water $(15 \mathrm{ml} / 5 \mathrm{ml})$. $\mathrm{LiOH}(0.16 \mathrm{~g}, 3.78 \mathrm{mmol}) / \mathrm{H}_{2} \mathrm{O}(5 \mathrm{ml})$ was added. The reaction mixture was stirred for $15 \mathrm{~h}$, the methanol/ water was evaporated, the residue was dissolved in water; the solution was then adjusted to $\mathrm{pH} 1$ with $\mathrm{HCl}$. The solution was extracted 3 times with ethyl acetate. The ethyl acetate was evaporated to yield $486 \mathrm{mg}$ (95\%) of ( $N$-octadecylcarbamoyl)acetic acid (B1-chain) as a white powder.

A B5-chain (( $N$-adamantylcarbamoyl)acetic acid) was prepared in the same manner as in the preparation of a B1-chain using adamantylamine in place of octadecylamine. ( $N$-Octadecylcarbamoyl)acetic acid $(300 \mathrm{mg}$, $0.843 \mathrm{mmol}$ ) was dissolved in $18 \mathrm{ml}$ dry dichloromethane on an ice bath; then, triethylamine $(0.234 \mathrm{ml}, 1.686$ $\mathrm{mmol}$ ) was added to the solution and stirred for $15 \mathrm{~min}$. BOP-Cl (bis(2-oxo-3-oxazolidinyl)phosphinic chloride, $214 \mathrm{mg}, 0.843 \mathrm{mmol}$ ) was added and stirred for $30 \mathrm{~min}$. Cryptofix K22 $(221 \mathrm{mg}, 0.843 \mathrm{mmol})$ was then added; and the reaction was allowed to proceed for $3 \mathrm{~h}$. The reaction mixture was then partitioned 3 times with water (pH 1)-chloroform. The organic layer was collected and dried over anhydrous sodium sulfate. After evaporation, an intermediate product 1 was obtained, and directly used for the next reaction step.

$\mathrm{N}$-Adamantylcarbamoylacetic acid (B5-chain, $200 \mathrm{mg}$, $0.843 \mathrm{mmol}$ ) was dissolved in $18 \mathrm{ml}$ dry dichloromethane in an ice bath; then, triethylamine $(0.234 \mathrm{ml}, 1.686 \mathrm{mmol})$ was added to the solution and stirred for $15 \mathrm{~min}$. BOPCl $(214 \mathrm{mg}, 0.843 \mathrm{mmol})$ was added and stirred for $30 \mathrm{~min}$. Product 1, obtained from the previous step, was then added, and the reaction was allowed to proceed for $24 \mathrm{~h}$. The reaction mixture was then partitioned 3 times with water ( $\mathrm{pH} 1)$-chloroform. The organic layer was collected and dried over anhydrous sodium sulfate. The product was separated by HPLC using methanol as the eluent to obtain K22B1 B5 as a white solid $(121.9 \mathrm{mg}$, yield $17.6 \%$ ). Satisfactory analytical data were obtained for K22B1B5 and ${ }^{1} \mathrm{HNMR}\left(270 \mathrm{MHz}, \mathrm{CDCl}_{3}\right)$; the spectral data are as follows: $\delta 0.88(\mathrm{t}, 3 \mathrm{H}), 1.25$ $(\mathrm{m}, 30 \mathrm{H}), 1.5-2.1(\mathrm{~m}, 15 \mathrm{H}), 3.21(\mathrm{~m}, 4 \mathrm{H}), 3.45(\mathrm{~m}, 2 \mathrm{H})$, $3.5-3.7(\mathrm{~m}, 24 \mathrm{H}), 7.73(\mathrm{br}, 1 \mathrm{H})$.

KDC-1 (4-[(4'-dimethylaminophenyl)azo]-1-octylbenzene). Sodium nitrite $(1.11 \mathrm{~g}, 16.0 \mathrm{mmol})$ was added to a THF solution of $p$-octylaniline $(3.0 \mathrm{~g}, 14.6 \mathrm{mmol})$ in an ice bath. Concentrated $\mathrm{HCl}$ was then added to the reaction mixture and stirred for $15 \mathrm{~min} . \quad N, N$-Dimethylaniline $(1.77 \mathrm{~g}, 14.6 \mathrm{mmol})$ was dissolved in THF, and added to the reaction mixture and stirred for $2 \mathrm{~h}$. The usual workup and further purification by HPLC yielded KDC$1(800 \mathrm{mg}, 16.1 \%)$. Satisfactory analytical data were obtained for KDC-1; the ${ }^{1} \mathrm{HNMR}\left(270 \mathrm{MHz}, \mathrm{CDCl}_{3}\right.$ ) spectral data are as follows: $\delta 0.85(\mathrm{t}, 3 \mathrm{H}), 1.28(\mathrm{~m}, 10 \mathrm{H})$, $1.65(\mathrm{~m}, 2 \mathrm{H}), 2.65(\mathrm{t}, 2 \mathrm{H}), 3.15(\mathrm{~s}, 6 \mathrm{H}), 6.75(\mathrm{~d}, 2 \mathrm{H}), 7.28$ (d, $2 \mathrm{H}), 7.78(\mathrm{~d}, 2 \mathrm{H}), 7.88(\mathrm{~d}, 2 \mathrm{H})$.

KDC-2 ( $N^{2}$-octadecyl- $N^{8}, N^{8}, 3$-trimethylphenazine2,8-diamine). Sodium hydride $(0.288 \mathrm{~g}, 10 \mathrm{mmol})$ was added to a solution of Neutral Red $(3.0 \mathrm{mg}, 10 \mathrm{mmol})$ in 
$\mathrm{Mg}^{2+}$-Ionophores

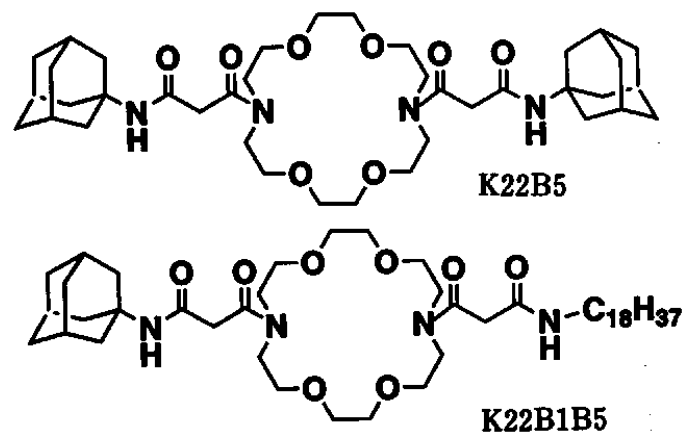

Liphophilic Dyes

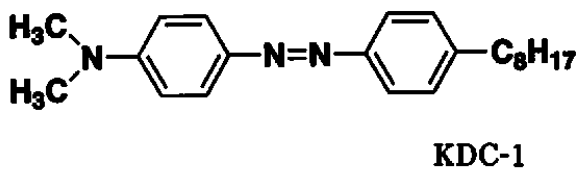

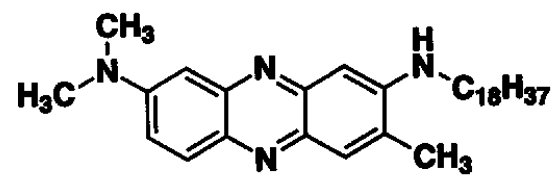

KDC-2

Fig. 2 Chemical structures of the magnesium ionophores and lipophilic cationic dyes.

dry DMF and stirred for $30 \mathrm{~min}$. Then 1-bromooctadecane $(3.34 \mathrm{~g}, 100 \mathrm{mmol})$ was added to the reaction mixture and stirred at $70^{\circ} \mathrm{C}$ for $3 \mathrm{~h}$. The usual workup gave KDC-2 as a brown solid (117.4 mg, yield $2.32 \%$ ). Satisfactory analytical data were obtained for K22B1B5 and ${ }^{1} \mathrm{HNMR}\left(270 \mathrm{MHz}, \mathrm{CDCl}_{3}\right)$ spectral data, as follows: $\delta 0.85(\mathrm{t}, 3 \mathrm{H}), 1.25(\mathrm{~m}, 30 \mathrm{H}), 2.38(\mathrm{~s}, 3 \mathrm{H}), 3.15$ $(\mathrm{s}, 6 \mathrm{H}), 3.35(\mathrm{q}, 2 \mathrm{H}), 4.2(\mathrm{br}, 1 \mathrm{H}), 6.9(\mathrm{~s}, 1 \mathrm{H}), 7.01(\mathrm{~d}, 1 \mathrm{H})$, $7.38(\mathrm{q}, 1 \mathrm{H}), 7.73(\mathrm{~d}, 1 \mathrm{H}), 7.93(\mathrm{~d}, 1 \mathrm{H})$.

The lipophilicity $\left(\log P_{\mathrm{o} / \mathrm{w}}\right.$; the partition coefficient of oil and water) of the newly synthesized ionophores and dyes were measured according to a previously reported procedure. ${ }^{4}$

\section{Preparation of $\mathrm{Mg}^{2+}$-sensing beads}

The chemical structures of the ionophores and the lipophilic cationic dyes are shown in Fig. 2. The $\mathbf{M g}^{2+}$ sensing lipophilic organic liquid was prepared by dissolving a neutral ionophore (K22B5 or K22B1B5), a lipophilic cationic dye (KDC-1 or KDC-2) and an anionic additive (sodium tetrakis[3,5-bis(trifluoromethyl)phenyl]borate; TFPB) in a lipophilic organic liquid (onitrophenyl octyl ether; NPOE) in a 10-ml glass vessel. The sensing liquid was coated on the surface of the pellicular ODS beads.

\section{Structure of the flow-through type $\mathrm{Mg}^{2+}$ optode}

The $\mathrm{Mg}^{2+}$ optode system is shown schematically in Fig. 3. A $0.05 \mathrm{M}$ Tris- $\mathrm{HCl}$ buffer solution, adjusted to $\mathrm{pH}$ 7.4, was supplied through a flow-through sensing system at a $1.0 \mathrm{ml} / \mathrm{min}$ flow rate using a pulse-free liquid delivery pump (Trirotar 2, JASCO, Tokyo, Japan). Sample solutions were introduced into the flow system through a 2-ml HPLC injector. The absorbance was measured with a Hitachi U-2000 spectrophotometer (Hitachi, Tokyo, Japan).

\section{Preparation of a test solution}

All of the sample solutions were prepared from the chloride salts of $\mathrm{Li}, \mathrm{Na}, \mathrm{K}, \mathrm{Mg}$ and $\mathrm{Ca}$ using a $0.05 \mathrm{M}$ Tris- $\mathrm{HCl}$ buffer solution adjusted to $\mathrm{pH}$ 7.4.

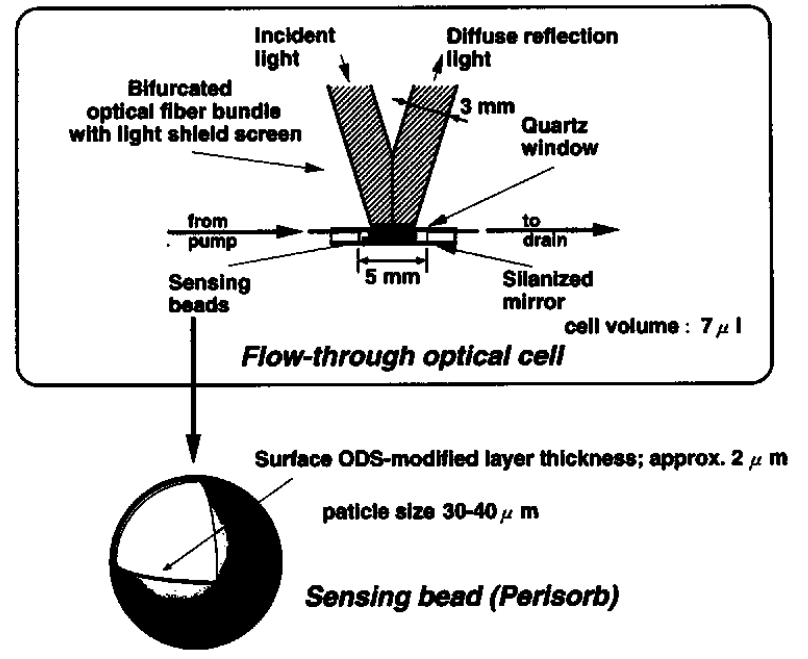

Fig. 3 Schematic views of a flow-through type optical sensor probe.

\section{Results and Discussion}

Performance of the newly synthesized lipophilic cationic dyes In this investigation, we synthesized two kinds of lipophilic dyes, KDC-1 and KDC-2. In order to examine the performance characteristics of the new dyes, a sensing liquid that contained the dye and only an anionic additive (TFPB) (without the magnesium ionophore) was prepared, and the response to various ions at various concentrations was measured. The typical experimental results are shown in Fig. 4, in which, with the use of KDC-1, a diazo-type dye, the ionic responses were in the order $\mathrm{K}^{+} \gg \mathrm{Na}^{+} \approx \mathrm{Ca}^{2+}>\mathrm{Li}^{+} \approx \mathrm{Mg}^{2+}$. This experimental response pattern was not advantageous, because KDC-1 appeared to promote the extraction of $\mathrm{K}^{+}, \mathrm{Na}^{+}$and $\mathrm{Ca}^{2+}$, the main source of interference in $\mathbf{M g}^{2+}$ sensing. In contrast to this dye, KDC-2 showed no relative preference for the alkali metal and alkaline-earth metal ions tested. This fact was interpreted to mean that 

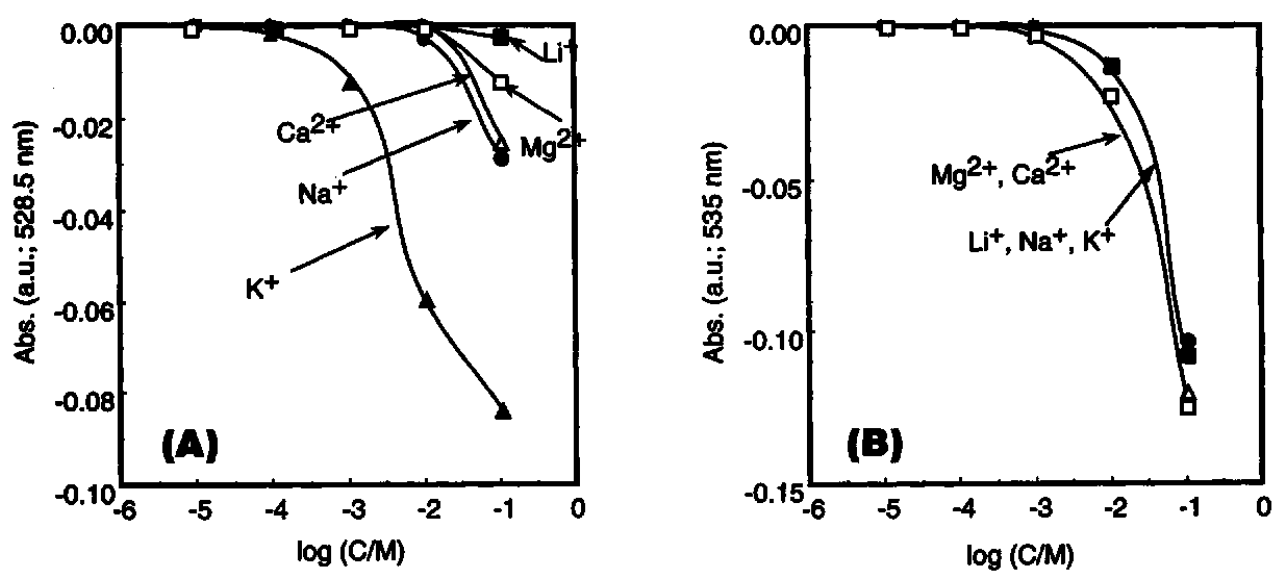

Fig. 4 Response curves to various ions of the optodes based on dyes (A) KDC1 and (B) KDC-2. Sensing layer composition: dye : TFPB $=2: 2$ ( $1 \mathrm{eq} .=1.5$ $\mu \mathrm{mol}$ in $40 \mathrm{mg}$ NPOE).
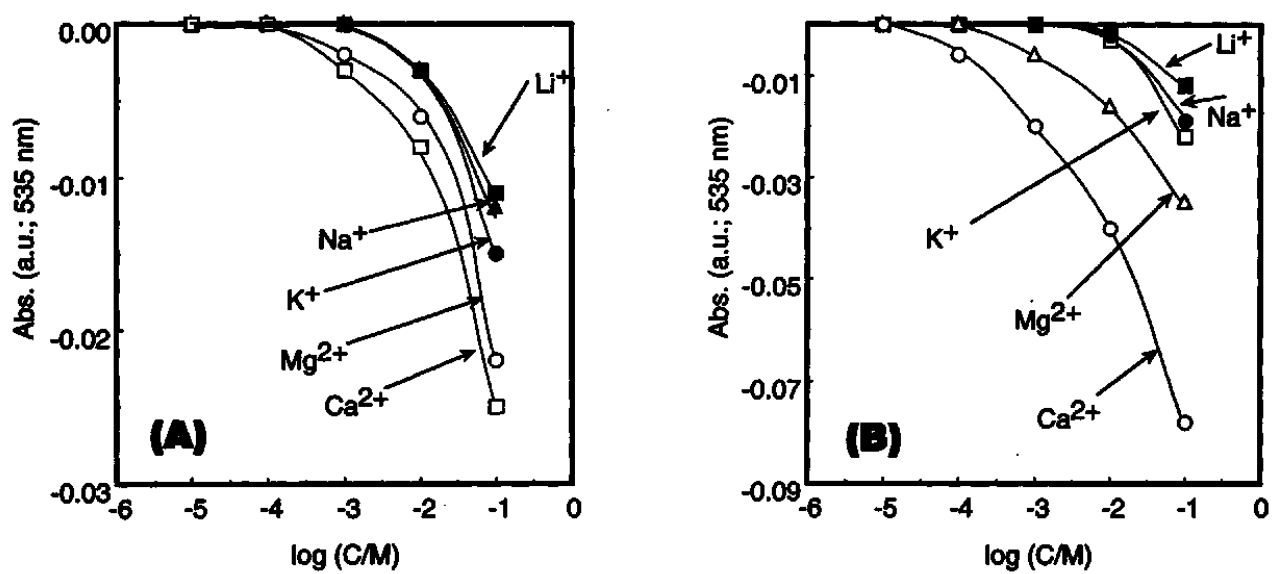

Fig. 5 Response curves to various ions of the optodes based on KDC-2 and ionophores (A) K22B5 and (B) K22B1B5. Sensing layer composition: Ionophore : KDC-2: TFPB $=1: 1: 0.5$ (1 eq. $=1.5 \mu \mathrm{mol}$ in $40 \mathrm{mg} \mathrm{NPOE})$.

KDC-2 effectively promoted the extraction of $\mathbf{M g}^{2+}$ compared to the optode using KDC-1. Therefore, the use of KDC-2 as a lipophilic cationic dye in a cation optode was recommended. Moreover, KDC-1 was not sufficiently lipophilic $\left(\log P_{\mathrm{o} / \mathrm{w}}=8.0 \pm 0.2\right)$ to provide an optode with a long lifetime.

\section{Performance of the magnesium ionophores}

Two kinds of magnesium ionophores, K22B5 and K22B1B5, have been tested as sensing components for a magnesium ion-selective optode. When these ionophores and KDC-2 were incorporated in sensing liquids, all of the optodes were observed to exhibit a high response to $\mathrm{Ca}^{2+}$, rather than to $\mathrm{Mg}^{2+}$. Such a phenomenon is often observed in $\mathbf{M g}^{2+}$-ISEs based on those ionophores, because the selectivities of those ISEs are strongly affected by the concentration of the anionic additive in the electrode membranes. ${ }^{20}$ As shown in Fig. 5, the optode based on K22B5 exhibited a better $\mathrm{Mg}^{2+} / \mathrm{Ca}^{2+}$ selectivity than the optode based on K22B1B5. However, in consideration for preparation of an $\mathrm{Mg}^{2+}$-optode with a long lifetime, the use K22B1B5 as the $\mathrm{Mg}^{2+}$-ionophore was advantageous, because this ionophore has a higher lipophilicity than K22B5. Therefore, K22B1B5 was used in further experiments for optimization studies.

\section{Optimization of the sensing liquid composition}

As stated in the previous section, the selectivity of the magnesium ionophores used in the experiments was dependent on the concentration of the anionic additive in the sensing membrane. Therefore, optimization of the membrane composition was crucial. Sensing liquids having various compositions, as given in Table 1, were prepared for optimization studies; the responses to various ions tested using the optodes based on those sensing liquids are shown in Fig. 6.

First, in order to experimentally optimize the 

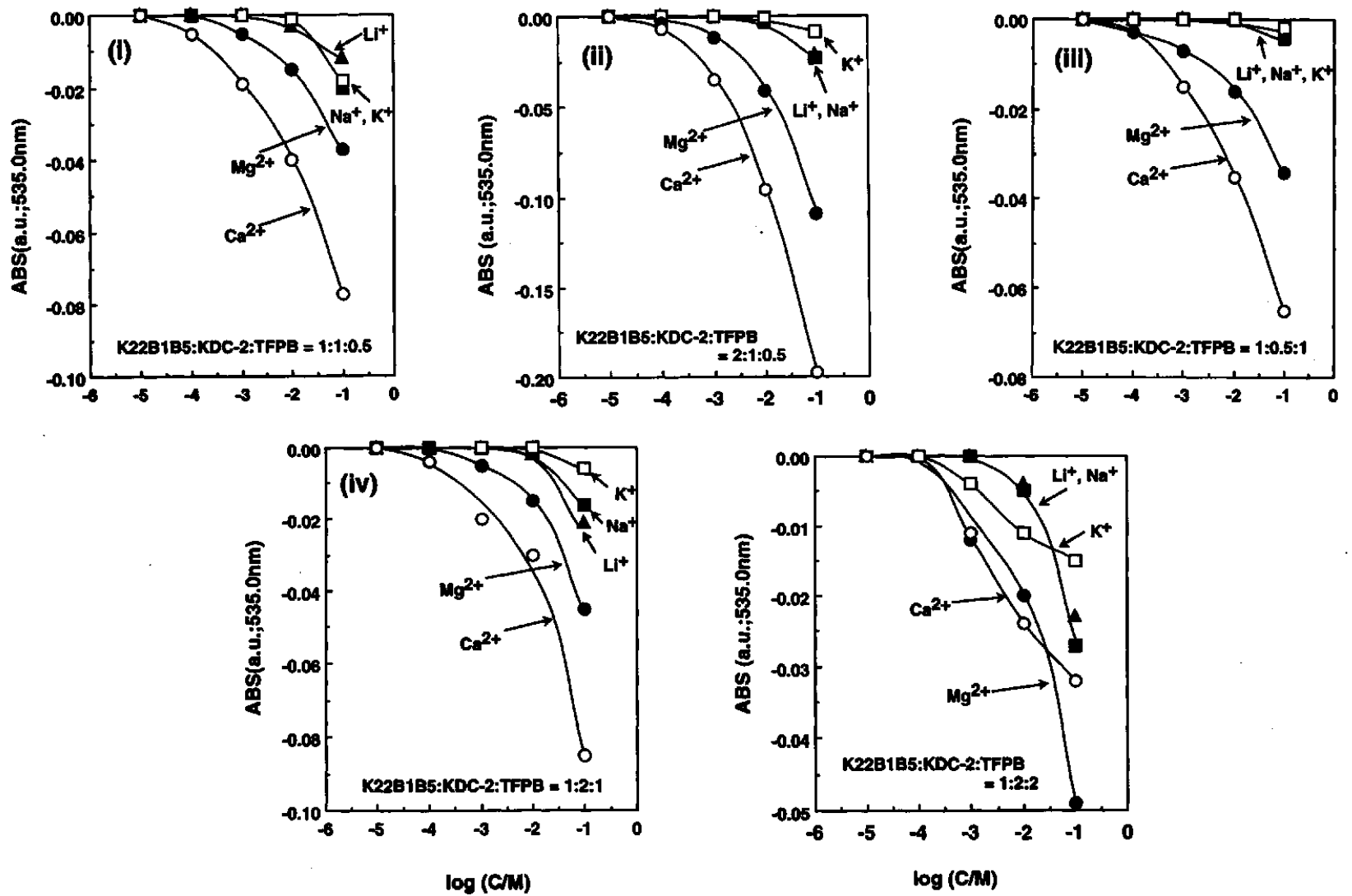

Fig. 6 Response curves to various ions of the optodes based on KDC-2, K22B5 and TFPB dissolved in NPOE at various compositions ( $1 \mathrm{eq} .=1.5 \mathrm{~mol}$ in $40 \mathrm{mg} \mathrm{NPOE}$ ).

Table 1 Sensing liquid compositions for optode optimization studies ( $1 \mathrm{eq} .=1.5 \mu \mathrm{mol}$ in $40 \mathrm{mg} \mathrm{NPOE}$ )

\begin{tabular}{lllllcc}
\hline & \multicolumn{5}{c}{ Composition } \\
\cline { 2 - 6 } & (i) & (ii) & (iii) & (iv) & (v) \\
\hline Ionophore (K22B1 B5) & 1 & 2 & 1 & 1 & 1 \\
Cationic Dye (KDC-2) & 1 & 1 & 0.5 & 2 & 2 \\
Anionic Additive (TFPB) & 0.5 & 0.5 & 1 & 1 & 2 \\
\hline
\end{tabular}

concentration of the ionophore, two sensing liquids having the mixing molar composition K22B1B5: KDC$2:$ TFPB of (i) $1: 1: 0.5$ and (ii) $2: 1: 0.5$ were prepared. When the ionophore was two-fold concentrated (composition ii), the response to divalent ions was much greater than that to monovalent ions. This fact indicates that K22B1B5 has an effective binding power to $\mathrm{Mg}^{2+}$. Although the optode response to $\mathrm{Ca}^{2+}$ was greater than that to $\mathrm{Mg}^{2+}$, the ionophore capability of binding not only to $\mathrm{Mg}^{2+}$ but also to $\mathrm{Ca}^{2+}$ is clearly indicated, a fact that was also observed in the ISE studies using K22B1B5 as a magnesium ionophore. In ISE studies, at a lower concentration of anionic sites, the ISEs even exhibited $\mathrm{Ca}^{2+}$-selectivity, rather than $\mathrm{Mg}^{2+} .{ }^{20}$

Secondly, the molar ratio of a cationic dye (KDC-2) to the ionophore (K22B1B5) was varied, and two kinds of sensing liquids were prepared, i.e., K22B1B5:KDC2 : TFPB of (iii) $1: 0.5: 1$; and (iv) $1: 2: 1$. Optodes with composition (iii) exhibited a similar selectivity pattern to that of an optode based on composition (i). To the contrary, with the molar ratio $\mathrm{KDC}-2 / \mathrm{K} 22 \mathrm{~B} 1 \mathrm{~B} 5=2$ (composition iv), the optode response to $\mathrm{Mg}^{2+}$ and $\mathrm{Ca}^{2+}$ ions was significantly increased, although the response to monovalent ions was also increased. This phenomenon was due to the fact that the dye concentration clearly affected the optode sensitivity.

To optimize the amount of the anionic additive, a sensing liquid with the composition K22B1B5: KDC$2:$ TFPB of $1: 2: 2$ (composition v) was prepared, which was doubly concentrated in anionic sites (TFPB) compared to composition (iv). An optode based on composition (v) showed a decrease in the optode response to $\mathrm{Ca}^{2+}$. Coinciding with the ISE optimization studies, the selectivity of the optodes for $\mathrm{Mg}^{2+}$ relative to $\mathrm{Ca}^{2+}$ and monovalent cations was increased with the increasing molar ratio of the anionic additive (TFPB). This fact indicates that TFPB is effective to increase the extractability of magnesium ion from the aqueous phase into the organic ion-sensing phase. Composition (v) was considered to be the best composition in view of the optode selectivity and sensitivity. 


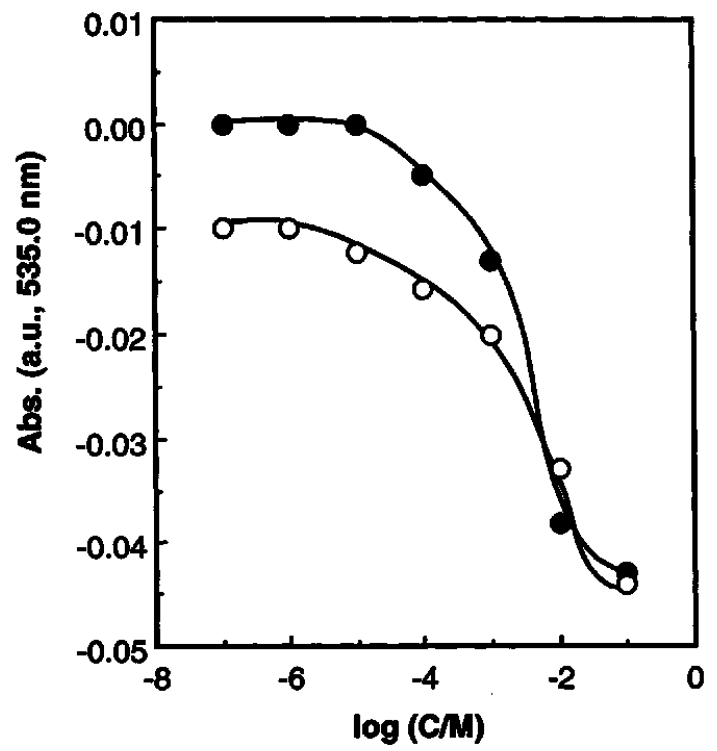

Fig. 7 Calibration curve for $\mathrm{Mg}^{2+}$ with and without background ions obtained with the optodes based on K22B1B5 and KDC-2. Sensing layer composition: K22B1B5 : KDC$2:$ TFPB $=1: 2: 2(1 \mathrm{eq} .=1.5 \mu \mathrm{mol}$ in $40 \mathrm{mg}$ NPOE$)$. The background ions were $3.0 \mathrm{mM} \mathrm{LiCl}, 150 \mathrm{mM} \mathrm{NaCl}, 5.0 \mathrm{mM}$ $\mathrm{KCl}$ and $1.2 \mathrm{mM} \mathrm{CaCl}_{2}$. (О) $\mathrm{Mg}^{2+}$ without interfering ion; (O) $\mathrm{Mg}^{2+}$ containing ions.

\section{Magnesium ion response curve}

The response curve of the $\mathrm{Mg}^{2+}$-optode of the optimized composition was measured for both test solutions not containing the background ions and those containing the background ions. The background ions were $3.0 \mathrm{mM} \mathrm{LiCl}, 150 \mathrm{mM} \mathrm{NaCl}, 5.0 \mathrm{mM} \mathrm{KCl}$ and $1.2 \mathrm{mM} \mathrm{CaCl}_{2}$, which represent a typical artificial serum sample. ${ }^{21}$ The response curves for $\mathrm{Mg}^{2+}$ are shown in Fig. 7. Although the background ion concentration was relatively high, the optode did not show severe interference in the concentration range of $5 \times 10^{-3}-10^{-1}$ $\mathbf{M ~ M g C l}$. Below this concentration range, the optode response showed serious interference due to the background ions.

\section{Response profile of the optode}

The response profile of the magnesium ion selective optodes based on K22B1B5 and KDC-2 with the optimized composition is shown in Fig. 8. The response time of the optode was ca. $1 \mathrm{~min}$, and the analysis time per sample was ca.4 min. This study provided a novel magnesium ion selective optode with a relatively fast response time. In a test solution of $10^{-1} \mathrm{M} \mathrm{MgCl}_{2}$ at pH 7.4 containing $3.0 \mathrm{mM} \mathrm{LiCl}, 150 \mathrm{mM} \mathrm{NaCl}, 5.0 \mathrm{mM}$ $\mathrm{KCl}$ and $1.2 \mathrm{mM} \mathrm{CaCl}_{2}$, a highly reproducible response was observed (see Fig. 8). Ionophore K22B1B5 and a color-changeable dye (KDC-2) are highly lipophilic $\left(\log P_{\mathrm{o} / \mathrm{w}}\right.$ of K22B1B5 and KDC-2 are 9.6 \pm 0.3 and $13.4 \pm 0.8$, respectively) and are suitable for the sensing components of the optode.

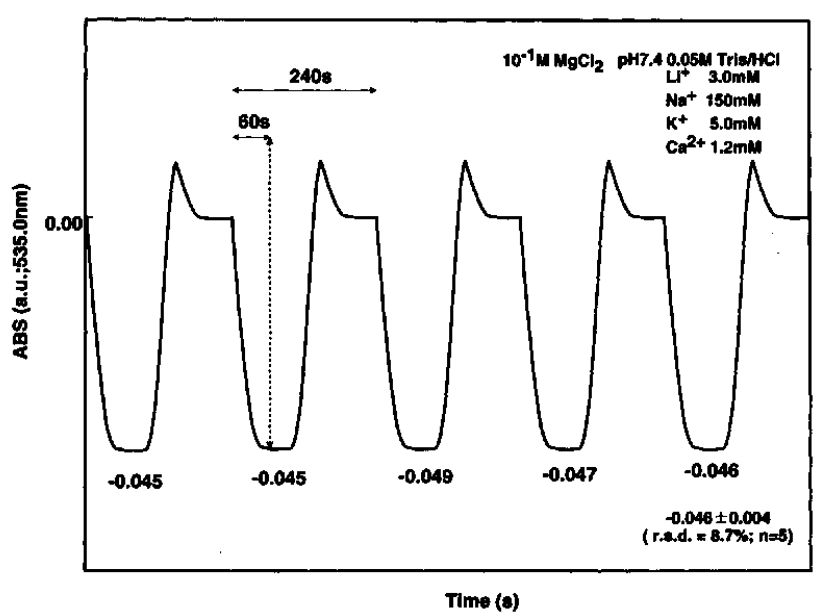

Fig. 8 Typical response profiles of the $\mathrm{Mg}^{2+}$-selective optode for the test solution containing $3.0 \mathrm{mM} \mathrm{LiCl}, 150 \mathrm{mM} \mathrm{NaCl}$, $5.0 \mathrm{mM} \mathrm{KCl}$ and $1.2 \mathrm{mM} \mathrm{CaCl}_{2}$. Sensing layer composition: K22B1B5: KDC-2:T FPB $=1: 2: 2(1 \mathrm{eq} .=1.5 \mu \mathrm{mol}$ in $40 \mathrm{mg}$ NPOE).

In summary, a magnesium-selective optode was successfully developed based on a novel neutral magnesium ionophore (K22B1B5) and a lipophilic cationic dye (KDC-2), as the first optode for magnesium ion. The optode exhibited high selectivity and sensitivity to $\mathrm{Mg}^{2+}$ over $\mathrm{Ca}^{2+}, \mathrm{Li}^{+}, \mathrm{Na}^{+}$and $\mathrm{K}^{+}$. However, the optode prepared in this work was still inapplicable for measurement of magnesium ion in the human serum $\left(\mathrm{ca} \cdot 10^{-4} \mathrm{M}\right.$ $\left.\mathrm{Mg}^{2+}\right)$; thus further development of a highly selective $\mathrm{Mg}^{2+}$-optode is required.

This work was partially supported by The Ministry of Education, Science, Sports, and Culture. D.S. would like to thank The Hitachi Scholarship Foundation for granting a studentship. We thank Dr. U. E. Spichiger of ETH (Zurich, Switzerland), the Europtrode III Chairperson, for her useful comments on this work.

This paper was presented at the 44th Annual Meeting of The Japan Society for Analytical Chemistry, Sapporo, September 28-30, 1995 and The Europt(r)ode III, Zurich March 31-April $3,1996$.

\section{References}

1. K. Suzuki, H. Ohzora, K. Tohda, K. Miyazaki, K. Watanabe, H. Inoue and T. Shirai, Anal. Chim. Acta, 237, 155 (1990).

2. K. Watanabe, E. Nakagawa, H. Yamada, H. Hisamoto and K. Suzuki, Anal. Chem., 65, 2704 (1993).

3. H. Hisamoto, K. Watanabe, E. Nakagawa, Y. Shichi and K. Suzuki, Anal. Chim. Acta, 299, 179 (1994).

4. H. Hisamoto, E. Nakagawa, K. Nagatsuka, Y. Abe, S. Sato, D. Siswanta and K. Suzuki, Anal. Chem., 67, 1315 (1995).

5. M. Lerchi, E. Reitter, W. Simon, E. Pretsch, D. A. 
Chowdhury and S. Kamata, Anal. Chem., 66, 1713 (1994).

6. M. Lerchi, E. Bakker, B. Rusterholz and W. Simon, Anal. Chem., 64, 1534 (1992).

7. K. Wang, K. Seiler, W. E. Morf, U. E. Spichiger, W. Simon, E. Lindner and E. Pungor, Anal. Sci., 6, 715 (1990).

8. K. Wang, K. Seiler, B. Rusterholz and W. Simon, Analyst [London], 117, 57 (1992).

9. W. E. Morf, K. Seiler, B. Rusterholz and W. Simon, Anal. Chem., 62, 738 (1990).

10. K. Seiler, K. Wang, W. E. Morf, B. Rusterholz, U. E. Spichiger and W. Simon, Clin. Chem., 37, 1350 (1991).

11. K. Seiler, W. E. Morf, B. Rusterholz and W. Simon, Anal. Sci. 5, 557 (1989).

12. U. E. Spichiger, R. Eugster, P. Gehrig, A. Schmid, B. Rusterholz, E. Haase, G. Rumpf and W. Simon, Fresenius' J. Anal. Chem., 341, 727 (1991).

13. U. E. Spichiger, Electroanalysis 5, 739 (1993).

14. R. Eugster, B. Rusterholz, A. Schmid, U. E. Spichiger and W. Simon, Clin. Chem., 39, 588 (1993).
15. R. Eugster, T. Rozatsin, B. Rusterholz, B. Aebersold, U. Pedrazza, D. Ruegg, A. Schmid, U. E. Spichiger and W. Simon, Anal. Chim. Acta, 289, 1 (1994).

16. Z. Hu, T. Buhrer, M. Muller, B. Rusterholz, M. Rouilly and W. Simon, Anal. Chem., 61, 574 (1989).

17. K. Suzuki, K. Watanabe, Y. Matsumoto, M. Kobayashi, S. Sato, D. Siswanta and H. Hisamoto, Anal Chem., 67, 324 (1995).

18. K. Seiler and W. Simon, Anal. Chim. Acta, 266, 73 (1992).

19. E. Bakker and W. Simon, Anal. Chem., 64, 1805 (1992).

20. D. Siswanta, Y. Matsumoto, S. Sato, H. Hisamoto, N. Yamamoto and K. Suzuki, Proc. of 69th Annual Meeting of the Chemical Society of Japan, Kyoto, Japan, March 1995; Abstr. 2C213.

21. D. Ammann, "Ion-Selective Microelectrodes", Chapter 7, Springer-Verlag, New York, 1986.

(Received November 18, 1996) (Accepted February 19, 1997) 